Revue de l'Institut des langues et cultures

d'Europe, Amérique, Afrique, Asie et Australie

18 | 2013

Les frontières dans le monde hispanique

Princesas de Fernando León de Aranoa (2005) o la invención cinematográfica de un espacio hospitalario

Fernando León de Aranoa's Pricesas: The Invention of an "Homely Space"

Olga Lobo

QpenEdition

Journals

Edición electrónica

URL: http://journals.openedition.org/ilcea/2143

DOI: $10.4000 /$ ilcea.2143

ISSN: 2101-0609

Editor

UGA Éditions/Université Grenoble Alpes

Edición impresa

ISBN: 978-2-84310-251-6

ISSN: $1639-6073$

Referencia electrónica

Olga Lobo, «Princesas de Fernando León de Aranoa (2005) o la invención cinematográfica de un espacio hospitalario », ILCEA [En línea], 18 | 2013, Publicado el 11 julio 2013, consultado el 19 abril 2019. URL : http://journals.openedition.org/ilcea/2143; DOI : 10.4000/ilcea.2143

Este documento fue generado automáticamente el 19 abril 2019.

(C) ILCEA 


\section{Princesas de Fernando León de Aranoa (2005) o la invención cinematográfica de un espacio hospitalario}

Fernando León de Aranoa's Pricesas: The Invention of an "Homely Space"

Olga Lobo

«Y en la cosa nunca vista de tus ojos me he

buscado

en el ver con que me miras.»

Antonio MACHADO

1 Cualquiera que se haya paseado por la geografía española y -especialmente- por ciudades como Madrid y Barcelona en los últimos veinte años, ha podido constatar una serie de cambios que han transformado el espacio urbano y a las gentes que lo recorren: nuevos comercios con aire cosmopolita, locutorios, colores, olores y sonidos venidos de otros lados, han impuesto un halo de diversidad y multiculturalismo inesperado a una España apenas amanecida del sueño de modernidad que se venía construyendo desde el restablecimiento de la democracia y particularmente, su integración en la Unión Europea.

Más allá de las impresiones, así lo confirman las estadísticas y estudios de la sociología y los organismos oficiales: España, apuntan los estudios, ha pasado de tener un 0,91 \% de ciudadanos extranjeros en 1991 a un $12 \%$ en $2012^{1}$. Fenómeno masivo, rápido e inesperado, como se han esforzado en demostrar diversas publicaciones en torno al tema aparecidas en el periodo ${ }^{2}$, que, tras una primera reacción de asombro obligó a la clase política a improvisar distintos modos de regular y controlar la situación.

3 Así, desde un primer intento en 1985 (Ley orgánica 7/85), se han sucedido decretos (1986/1996), nuevas leyes (2000), reformas a las leyes $(2003,2009)$ y nuevos reglamentos y decretos $(2011)^{4}$. Esfuerzos de regulación y control que se han ido acompañando de una 
reflexión más profunda en torno a la manera de integrar $\left(\mathrm{o} \mathrm{no} \mathrm{o}^{5}\right)$ de forma óptima a los nuevos ciudadanos ${ }^{6}$.

4 Por su parte, los medios informativos comenzaron paulatinamente a interesarse por este nuevo «fenómeno» que se convertiría poco a poco en noticia (no siempre, o casi nunca, por «buenas razones» $»^{7}$ : en 2006 el periódico El Mundo publica un especial dedicado a los inmigrantes, su situación, sus esperanzas y anhelos así como los entresijos más íntimos de lo que las leyes acarrean; ; asimismo El País publica el 6 de julio de 2008 un reportaje especial sobre lo que llama la "generación I», los nacidos en España de padres (o uno de ellos) extranjeros y que «encarnan el punto de inflexión de una sociedad que cambia de rostro»".

5 Este fenómeno migratorio inesperado se destaca, como señalábamos, por su carácter exponencial y al mismo tiempo participa de una dinámica que traspasa las fronteras españolas. Se trata, en efecto, de un fenómeno universal, con creciente diversificación en la procedencia de los flujos y lugares de asentamiento, marcando así su carácter de «global», tal como indica, entre otros, Cristina Blanco ${ }^{10}$.

6 Los flujos migratorios que «afectan», por consiguiente, también a España, forman parte del fenómeno más amplio de la globalización que caracteriza nuestra era. En un mundo donde las posibilidades de comunicación son «ilimitadas», la circulación de la información se universaliza, el mercado se «mundializa» y los intercambios transnacionales se generalizan, los movimientos migratorios parecen haberse transformado en un recurso de desarrollo personal y laboral de primer orden.

7 Ahora bien, parece que esta serie de fenómenos implicados en la globalización provoca en nuestras sociedades occidentales dinámicas de reacción de proporción inversa, lo que no deja de ser en cierto sentido paradójico: a mayor «globalización» menor tolerancia en las fronteras...

8 Así, por un lado, como explica Jürgen Habermas en su ensayo de 1998 Die postnationale Konstellation. Politische Essays ${ }^{11}$, la globalización es un proceso (fenómeno en movimiento, entonces, y por tanto inacabado) inevitable y que tendrá (que está teniendo de hecho) como consecuencia la constitución de sociedades multiculturales. Estas sociedades multiculturales hoy en formación suponen, en última instancia, la superación del Estado nación (entendido como garante de la aplicación de principios democráticos, derechos de los ciudadanos, etc., que ha permitido el funcionamiento de nuestras democracias hasta la actualidad) hacia lo que él llama una constelación postnacional.

Por otro, frente a la realidad innegable de una evolución de los estados europeos hacia sociedades multiculturales favorecida por la porosidad de múltiples fronteras (económicas, informativas, comunicacionales...) una reglamentación cada vez más estricta parece tratar de transformar las fronteras políticas europeas en verdaderas «fortalezas».

Según explica, pasados algo menos de diez años de la publicación de Habermas ${ }^{12}$, Michel Foucher en L'obsession des frontières (Perrin, 2007), «la escena fronteriza mundial está marcada por un doble movimiento de obsolescencia y de resistencia de sus atributos» ${ }^{13}$. Este mundo, como veíamos, cada vez más «fluido», ha producido en estas casi dos últimas décadas (desde 1991 a 2007) más de veintiseis mil kilómetros de frontera política; la nueva era de la mundialización, parece tener como corolario, comenta Foucher, la obsesión de la delimitación. El hombre moderno, continua Foucher, paga su libertad de ir y venir con una vigilancia creciente de acentos orwellianos ${ }^{14}$. 
L'obsession des frontières qui envahit la représentation contemporaine du monde se décline selon les lieux en impératifs de sécurité stratégique [...] ou en dispositifs de protection des établis contre les marginaux et les flux jugés indésirables. Les frontières se sont transformées en "membranes asymétriques", autorisant la sortie mais protégeant l'entrée d'individus venant de l'autre côté ${ }^{15}$.

11 La obsesión por la frontera se traduce en un repliegue cuya visibilidad más inmediata vendría dada por las políticas gubernamentales de orden proteccionista pero que se alimenta (se retroalimenta) igualmente con representaciones sociales que favorecen la calificación, estigmatización, de la inmigración como "problema», y del inmigrante como amenaza. Los gobiernos se ven obligados a marcar su «autoridad territorial» a través de leyes ad hoc que tranquilicen a sus «nacionales», estos, a su vez, inmersos en la agitación de nuevas caras y la proliferación de reacciones políticas, en ocasiones, desmedidas, crean estereotipos y buscan reconfortarse/protegerse en ideas preconcebidas...

Como señala Yves Charles Zarka ${ }^{16}$ en el editorial del número de su revista dedicado a la inmigración ${ }^{17}$, el "problema» de la inmigración (o la inmigración como "problema») es, en efecto, una construcción ideológica basada no en realidades o hechos sino en pasiones (reacciones por tanto irracionales) tales como el miedo ${ }^{18}$.

Este miedo estaría sustentado en tres representaciones del inmigrante: como individuo potencialmente peligroso (enemigo interior o amenaza contra la identidad nacional), como competencia desleal en el plano económico (ofrece su trabajo a menor coste, degrada las condiciones sociales y acapara los empleos de los «nacionales») y en tanto individuo étnicamente inasimilable (cuerpo extranjero heterogéneo a la nación, ciudadano de segundo orden) ${ }^{19}$.

Reacciones proteccionistas, entonces, que se extienden por todo el territorio europeo y que desafían, como veíamos con Habernas, nuestra concepción de sociedades democráticas, en la medida en que el desarrollo efectivo del multiculturalismo nos insta a romper con hábitos adquiridos, y a reinventar nuevas formas de «ciudadanía» donde la solidaridad entre ciudadanos que caracterizaba al Estado Nación deberá (en una proyección ideal) hacerse extensible, inclusiva, a los diversos rostros que conforman nuestras nuevas realidades sociales ${ }^{20}$.

Así, en el caso de España, el carácter repentino, masivo e incontrolable (al menos en términos de percepción) de la inmigración ha generado - superada la primera etapa de incredulidad/curiosidad- una convivencia conflictiva que se traduce por ciertas formas de «territorialización» frente al extranjero (contra el inmigrante), como una suerte de imposición de las llamadas fronteras culturales ${ }^{21}$.

16 Surgen, de este modo, viejos discursos identitarios procedentes mayoritariamente del concepto de nación «nacional-católico» del franquismo (concepción unívoca, estática de la Historia y de la construcción de la identidad nacional ${ }^{22}$ ), discursos postcoloniales, o abiertamente racistas que entran en franca contradicción con la constitución de esa España moderna y democrática que mencionábamos al principio.

En definitiva, lejos aún de la proyección ideal planteada por Habermas, España ha pasado del asombro inicial de los primeros años frente al fenómeno de la inmigración a la etapa de lo que Joaquín Arango Vila Belda denomina el «fin de la inocencia» es decir, hacia el «deterioro de la valoración social del fenómeno» ${ }^{23}$.

Diversas manifestaciones artísticas han incluido recientemente en sus discursos tanto las transformaciones sociales provocadas por la inmigración en nuestro país como las 
reacciones frente al fenómeno. Entre ellas, sin duda de forma más visible, el cine. Este es el caso de la obra objeto de nuestro estudio.

La película Princesas (Fernando León de Aranoa, 2005) ${ }^{24}$ se inserta en la emergencia de un cine social de estética intimista que su director venía explorando en sus películas anteriores (Barrio, 1998 o Los lunes al sol, 2001, entre otras). En ella León de Aranoa pone en escena, cuenta, muestra, una historia que incluye en su complejo entramado una mirada sobre la inmigración y su incorporación a la sociedad española. $O$ dicho de manera más convencional (aunque reductora), se trata de un filme que trata del tema de la inmigración y sus conflictos. O mejor dicho aún, aborda con su mirada realidades en las que el ser humano se confronta con el otro, lo otro, como veremos, en su búsqueda de una vida mejor. Ver de qué manera lo hace es el propósito de nuestro artículo.

En la historia de este binomio cine-inmigración en España, que ha sido objeto de un número relativamente considerable de estudios y análisis ${ }^{25}$-desgraciadamente desde un enfoque a menudo demasiado utiliratista, sociológico o impresionista del análisis fílmico -, encontramos un punto de partida: Las cartas de Alou (Montxo Armendáriz, 1990) que coincide cronológicamente con el inicio del proceso de transformación de España en país receptor de inmigrantes. A esta película le sucedieron «muchas» otras, de éxito e impacto desigual: en 1996, Bwuana (Uribe), En la puta calle (E. Gabriel), Menos que cero (E. Tellería), Susanna (A. Chavarrrías), La sal de la vida (E. Martín), Cosas que dejé en La Habana (Manuel Gutiérrez Aragón, 1997), Flores de otro mundo (Icíar Bollaín, 1999), La fuente amarilla (Miguel Santesmases, 1999), Saïd (Llorenç Soler, 1999), etc. ${ }^{26}$. Son películas que, como se ha afirmado, "ponen rostro a los colectivos más afectados por la globalización y cierto recrudecimiento en la política social» y forman parte de una de las tendencias más marcadas del cine español de cambio de siglo, esto es, su repolitización ${ }^{27}$.

El interés del filme elegido es, en primer lugar, simple y llanamente, su riqueza fílmica: es una película cuya construcción (plástica, visual...) desborda el tratamiento del tema por el simple argumento o contenido de la fábula. Por otra parte, pertenece a un periodo (seguda mitad de la primera década del siglo) en el que, como vimos, la sociedad española sale del periodo inicial de sorpresa y comienza a «descubrir» en torno suyo a esos rostros que finalmente han venido para quedarse... ${ }^{28}$

Desde cierta marginalidad, el microcosmos reducido de un grupo de prostitutas y una peluquería de señoras en la que se reúnen, León de Aranoa logra introducirnos con su mirada «glocal» en todo un universo en plena trasformación que (nos) cuestiona y busca tambalear, en último término y de manera definitiva, nuestra posición en el mundo, un mundo, por otro lado, lleno de promesas.

Con su película, Fernando León de Aranoa explora, como ya lo habían hecho otras películas en torno a la emigración, aspectos ya comentados tales como la representación del inmigrante según una lógica «nacionalista» (basada en diferencias culturales, étnicas o sociales que lo transforman en una amenaza); pone en escena igualmente discursos identitarios post-coloniales o racistas que dan cuenta de ese deterioro en la valoración del fenómeno del que hablábamos pero, por otro lado, Aranoa nos ofrece además un complejo fílmico que desde la fábula nos implica en la proyección de un espacio nuevo, un espacio otro donde sería posible operar la transformación de la hostilidad a la hospitalidad.

Para guiarnos e implicarnos en dicha transformación ${ }^{29}$, Aranoa nos llevará por distintos espacios (narrativos y visuales) haciéndonos partícipes de la transgresión de diversas fronteras hasta, en última instancia, empujarnos a franquear, aunque sea de manera 
simbólica, la frontera definitiva y última que se interpone entre la realidad, el espectador y la obra: la pantalla. Dicho de otro modo, Aranoa nons invita a ir más allá del caracter ficcional del filme incomodando nuestra situación de espectador pasivo, interrogando nuestra posición en ese espacio que propone a nuestra mirada. Veamos cómo.

\section{Princesas, un cuento de hadas nada convencional: el encuentro con la otredad}

Princesas cuenta la historia del encuentro conflictivo y progresiva amistad entre dos chicas, dos prostitutas, una española, Cayetana (Caye, interpretada por Candela Peña), otra dominicana, Zulema (Zule, interpretada por Micaela Nevárez) ${ }^{30}$. Las primeras secuencias del filme (desde los créditos iniciales) permiten situarnos en el mundo de Cayetana -cuyo punto de vista nos guiará durante prácticamente toda la película.

«Caye» es una chica de clase media, hija menor de una familia articulada en torno al «matriarcado» que ejerce una mujer (que se llama de hecho Pilar) aferrada a la obsesión de existir para alguien (se envía flores fingiendo tener un admirador - que sería además su difunto marido cuya muerte evidentemente niega-), un hermano bastante insignificante que sigue la corriente de los acontecimientos que suceden a su alrededor dejando, simplemente, que sucedan y su mujer, directora de un Instituto de secundaria. Meticulosa en su trabajo (establece reglas de conducta a sus clientes, lleva una rigurosa contabilidad con registro de fechas y «volumen de negocios»...), «Caye» aparece representada como una joven algo soñadora y en cierto sentido ingenua.

La mirada de Cayetana, de la que hablaremos en detalle infra, se nos ofrece primero por una entrada en su intimidad (la intimidad de sus espacios, su cuarto en el piso donde vive sola ${ }^{31}$ ) y pronto en su «universo maravilloso» a través de los diálogos, suerte de monólogos compartidos, en realidad, porque son una especie de reflexiones en voz alta que dan cuenta de un lado, como decía, «maravilloso» en la invención y visión del mundo de Cayetana $^{32}$.

En efecto, Caye, como descubriremos a lo largo del relato, se encuentra de alguna manera encerrada en el mundo de la infancia ${ }^{33}$. En este sentido, sufre diversas carencias que de forma explícita o implícita hacen referencia a esta situación: la ausencia de pecho (está ahorrando para ponerse unos implantes mamarios), una relación infantilizante con su madre, o el anhelo de un «príncipe azul» que, como ella dice, pueda «venir a buscarla a la salida del trabajo»... De alguna manera, la prostitución, oficio en el que no se sabe muy bien por qué ha entrado, funcionaría como un simulacro existencial con el que colmar dichas carencias.

Así, su mundo imaginativo, sus sueños, su espacio infantil son el refugio donde preservar una inocencia en perdición y la prostitución es la manera que tiene de «jugar» a ser adulta.

La historia de Zulema sigue, por su parte, un esquema digamos «tradicional» de muchas mujeres inmigrantes: dominicana indocumentada, lleva cierto tiempo en España esperando los papeles para instalarse, encontrar un trabajo «normal» y poder traerse, con sus ahorros, a su hijo. Zulema vive con la angustia de que la policía la detenga, y se aferra a la ilusión de un permiso de residencia que un funcionario corrupto le ha ofrecido (y con el que, entre tanto, se ve obligada a acostarse gratis como adelanto del favor prometido). 
31 Aferradas cada una de ellas a una esperanza, una ilusión, estas dos princesas «alejadas de su reino» (su país para Zulema, otra vida menos dura para Caye), encuentran un terreno de encuentro en el que estar menos solas.

Esta es la base argumental de la fábula de Princesas que funciona como una suerte de cuento maravilloso reinventado que puede «leerse», de hecho, adoptando parcialmente el esquema elemenal basado en las funciones establecidas por Vladimir Propp ${ }^{34}$ :

1) la heroina (Zulema), se aleja de su reino ${ }^{35}$,

2) tiene prohibida la estancia en España puesto que carece de papeles de residencia.

3) Transgrede tal prohibición instalándose en España de manera ilegal.

4) Un antagonista (el funcionario corrupto) entra en contacto con la heroína.

5) Obtiene información sobre ella (Zulema necesita papeles) y

6) mediante engaño se apodera de ella (de su alma, de su cuerpo, de sus ilusiones), atribuyéndose la función de falso héroe.

7) La heroina/víctima le ofrece su complicidad, al confiar en él.

8) El antagonista abusa de ella y la agrede (violación).

9) La fechoría se hace pública (Zule, después de ser violada por su antagonista acude al hospital, Caye la asiste),

10) Zulema se da cuenta de que nunca obtendrá los papeles (el antagonista queda desenmascarado).

11) La heroina se enfrenta a su antagonista.

12) La heroina queda marcada (marca son los golpes que Zulema recibe del funcionario, pero también la enfermedad del sida que ha contraído por no protegerse en las relaciones, obligada por las condiciones de trabajo).

13) La heroina obtiene una victoria parcial/castigo sobre su antagonista: Zulema se venga de su malhechor acostándose una última vez para transmitirle el sida.

Por otro lado:

14) Caye somete primero a Zulema a prueba: la desafía en su posición de otro, de extranjera ${ }^{36}$.

15) La heronia, supera la prueba ${ }^{37}$.

16) Se hacen amigas, la heroina es reconocida, Caye (donante) la ayuda dándole un objeto mágico (el dinero que ha ahorrado para la operación de cirujía).

17) Este regalo permite a Zulema regresar a su reino. maravillosa con la que sueña ${ }^{38}$ ) que transgrede lo convencional de su vida familiar haciéndose prostituta y se prohibe un acceso a la «verdad» a través de los no dichos, lo silenciado, lo oculto, los tabúes o los engaños que sustentan las relaciones familares en las que ha crecido. Ella también se enfrenta, desde su fantasía, a todos los antagonistas que le impiden realizar su sueño y finalmente, ella tamibién recibe un regalo en la amistad de Zulema que la llevará a cambiar de rumbo, elegir, de algún modo un camino nuevo.

El esquema narrativo establece, de este modo, un paralelismo entre las dos historias (Caye y Zule comparten como hemos visto similares miserias y trayectorias vitales). Dicho paralelismo propone, además, una resolución del conflicto inicial basada en valores universales (la amistad, la entreayuda, la simpatía...) haciendo que la condición de inmigrante de Zulema resulte superada por su dimensión humana. En este sentido la historia de Princesas parece apuntar a la eliminacioón de la diferencia a través de un encuentro hospitalario con el otro, lo otro. La también marginalidad de Caye que la convierte en «otro» para su familia y para la sociedad, hace que la frontera entre los roles 
que una y otra juegan (Caye nacional, Zule extranjera; Caye «anfitriona», Zule «invitada»; Caye «yo», Zule «el otro») se desdibujen.

Los viajes - tanto real de Zulema como simbólico de Caye- son, en última instancia, búsquedas desde el equilibrio inestable del funanbulista, situación vital que ambas comparten, cada una desde sus problemáticas. En un pasaje que reúne de nuevo a las dos protagonistas, Caye entabla la siguiente conversación (41:52):

Hice un curso del INEM de maquillaje para películas y otro de modelo, de pasarela, pero lo tuve que dejar porque no tenía equilibrio [...] yo es que nunca he tenido, de pequeña me caía todo el rato, hubo un día en que me caí siete veces, mi madre me llenaba los bolsillos de arena para que pesara más y no me cayera. Así que claro, como para caminar por una pasarela. Por eso me gustan tanto los equilibristas, yo debería casarme con un equilibrista para compensar ¿En tu país hay equilibristas? (A lo que Zulema responde): diez millones.

Zulema se convierte progresivamente en una especie de espejo invertido de Cayetana: la relación con ella es una puerta hacia otra realidad que va abriéndole los ojos, enfrentándola con la inmediatez concreta y terrible de la existencia. Su amistad es ese regalo mágico que compensa sus carencias y que le hace, al final del relato, asumir la verdad, hacerla «pública» y establecer una relación más frontal, directa y auténtica con su entorno.

Al final de la historia Caye regresa a su casa tras acompañar a Zulema al aeropuerto. De regreso, las cosas han evolucionado: Pilar ha dejado de enviarse flores y Caye se libra a desvelar, a través de la historia de Zulema, su propia realidad. Hablándoles de la partida de Zulema Caye dice (1:43:37): «es que era puta, era puta y no podía más [...] se ha ido, ... quería estar con su familia». A pesar de que Cayetana no cuenta la verdad completa sobre ella misma, indirectamente, a través del juego de miradas que se establece entre ella y su madre (Caye responde a su hermano pero mira también y sobre todo a su madre que, en silencio, no deja de observarla, estupefacta) así como del plano detalle del teléfono que sigue la mirada de la madre mientras Caye se levanta para llevar su plato a la cocina ${ }^{39}$, se puede suponer que Pilar ha comprendido la procedencia y motivación de las llamadas misteriosas que su hija recibía siempre en estas reuniones familiares y a las que Caye no respondía.

Si, por un lado, la atmósfera maravillosa de la historia permite el contraste con la dureza de las situaciones que atraviesan las protagonistas y así, un acercamiento original al tema que lo hace más abordable para el espectador, por otro, la dislocación del esquema de cuento maravilloso, gracias a un final no tan feliz, menos tradicional pero más «realista», nos ofrece la posibilidad de acercarnos al lado más humano de las protagonistas sin caer ni en su victimización ni en su condena. Podemos afirmar, en este sentido, que con la transgresión del esquema narrativo de cuento maravilloso, el director efectúa una primera interpelación al espectador que busca la implicación afectiva, sin maniqueismos, con ambas protagonistas. Una identificación que, no obstante, no excluye la distancia crítica que necesita la pregunta implícita de la película.

La fábula de Princesas se presenta, en definitiva, como un cuento urbano, una historia de barrio, cercana, cotidiana, divertida por momentos, emotiva, en la que sus personajes, auténticos, próximos, consiguen nuestra empatía y nos conducen por un camino de lucha por la autenticidad. El filme Princesas, tomando las formas diversas y reconocibles de historia fabulosa, de comedia «ligera», de drama social, logra interpelarnos afectivamente a través de la empatía con sus dos protagonistas, superando las diferencias que pudieran 
existir entre ellas y nosotros espectadores, reuniéndonos en nuestra condición de ser humano implicado con nuestro entorno.

41 El ambiente de cuento de hadas sui generis, la autenticidad de los personajes, la iluminación natural que acentúa la franqueza de los desnudos, de los cuerpos, de los gestos, de las miradas, la crudeza y dureza de algunas imágenes, la nostalgia, y una mirada sin florituras (y sin sordidez) del «problema»/ los problemas con los que se enfrentan ambas mujeres dejan, no obstante, espacio para la esperanza, esta vez sí, corolario feliz de una historia que es al fin y al cabo una oda a la amistad y a la alegría-apesar-de-todo ${ }^{40}$, una manera de permacecer en equilibrio en la cuerda floja de la vida.

\section{La frontera de cristal: el espacio del otro «ajeno»}

En el apartado precedente hacíamos alusión al carácter conflictivo inicial de la relación entre Caye y Zulema. El planteamiento y posterior resolución del conflicto se desarrolla, en efecto, en torno a la condición de inmigrante de Zulema: una barrera de incomprensión y desconfianza separa a Caye (y su mundo) de Zulema.

La distancia que en principio las separa viene representada en la película a través del escaparate de la peluquería del barrio donde Caye se reúne con otras prostitutas para hablar de sus cosas: la peluqería Gloria. Este ventanal, auténtica frontera de cristal que compartimenta el espacio entre un aquí de las prostitutas «autóctonas» y un allí de las inmigrantes, las «otras», se muestra durante prácticamente toda la película (hasta 1:01:36) desde el interior de la peluquería como queriendo subrayar su calidad de trinchera, de refugio, de defensa contra la amenaza exterior y también de punto de observación, suerte de garita desde donde controlar los movimientos del exterior.

Así lo observamos en la secuencia que vamos a analizar (9:45 a 11:30) donde las conversaciones entre "autóctonas» sobre el «problema» de la inmigración sintetizan el acervo de estereotipos y representaciones mentales del otro como amenaza, como competencia desleal, de los que hablábamos en la introducción a nuestro artículo. Veamos la escena:

Plano general descriptivo de la plaza donde se pasean las prostitutas (la mayoría de color): tras una serie de movimientos panorámicos que muestran a las chicas y dejan ver un coche de policía que entra y sale de campo de derecha a izquierda hasta detenerse, la cámara retrocede y entra en campo el sonido de un secador que se superpone a la música que acompañaba el movimiento de cámara anterior, como una suerte de transición entre exterior/interior (de la peluquería). La cámara continúa su movimiento de retroceso hasta introcucirse (tras un corte casi imperceptible) detrás del ventanal/frontera de la peluquería desde el que una de las chicas, Caren, observa (su rostro en escorzo a la izquierda del plano, de perfil, desenfocado) el exterior. Tras un movimiento (cámara subjetiva) la chica se da vuelta e inicia una conversación (participan Caren / Caye y las dos peluqueras) paradigmática de lo que serán el resto de conversaciones de la peluquería, en términos de contenido, de ritmo (un ritmo acompasado por los planos/ contraplano entre ellas y la mirada dirigida al exterior: la plaza, siempre desde el interior de la peluquería) así como de discurso. Un discurso donde intervienen «saberes» (distorsionados) populares en materia de economía, por ejemplo, influenciados por la televisión y un uso de conceptos de exactitud más que dudosos o también prejuicios, estereotipos raciales... 
Caren: -Eso es lo peor... lo peor Gloria, tú hazme caso que desde que han «llegao» estas, es la selva, por 20 euros se la dejan meter y hasta por 15 he visto yo algunas, [...] / Gloria: -Pero a los tíos les gusta, por la novedad o por lo que sea, pero les gusta / Caren: -Gloria, yo trabajo la mitad, desde que están estas en el barrio, la mitad/ Gloria: -Pobrecitas pues algo tendrán que hacer, ¿no?, si vienen será porque en sus países no hay trabajo / Caren: -pero ¿qué pasa que allí la gente no folla? porque en algún sitio han aprendido / Caye: - no las defiendas tanto, Gloria, que si vinieran aquí a montar peluquerías seguro que no te daban tanta pena / Aprendiz de peluquería: - ¡sois unas racistas! / Caren: - no, [...] lo que pasa que te confundes, no es un problema de racismo, corazón, es un problema de mercado, [...] pero no el de ahí de la esquina que tú conoces, del otro, del de la demanda y la competencia, lo que pasa es que no hay demanda para todos, ni competencia, lo dijo el ministro de economía el otro día en la tele, que aquí todo dios llega y piensa que puede hacer lo que le salga de los huevos, y mira, no... / Caye: $-i$ el ministro de economía dijo eso ? / Caren: - lo de los huevos no lo dijo, eso lo digo yo, pero que lo pensaba, vamos... ese señor es ministro, un poco sabrá de lo que está hablando, me parece a mí, de mamadas sabes tú más Caye, pero de economía... el ministro de economía ${ }^{41}$. deciamos, incluyéndole en el punto de vista de Caye y sus amigas, manteniéndole a la misma distancia que a ellas de las «otras». Somos, así, espectadores del transcurso de los hechos y como tales nos situamos en esa distancia espacial que es al mismo tiempo espacio físico y simbólico donde el otro nos es extraño, extranjero. Este espacio es espacio de la ignorancia, de la incertidumbre, espacio abierto a todo tipo de elaboraciones mentales sobre ese otro que se presenta como efectivamente ajeno.

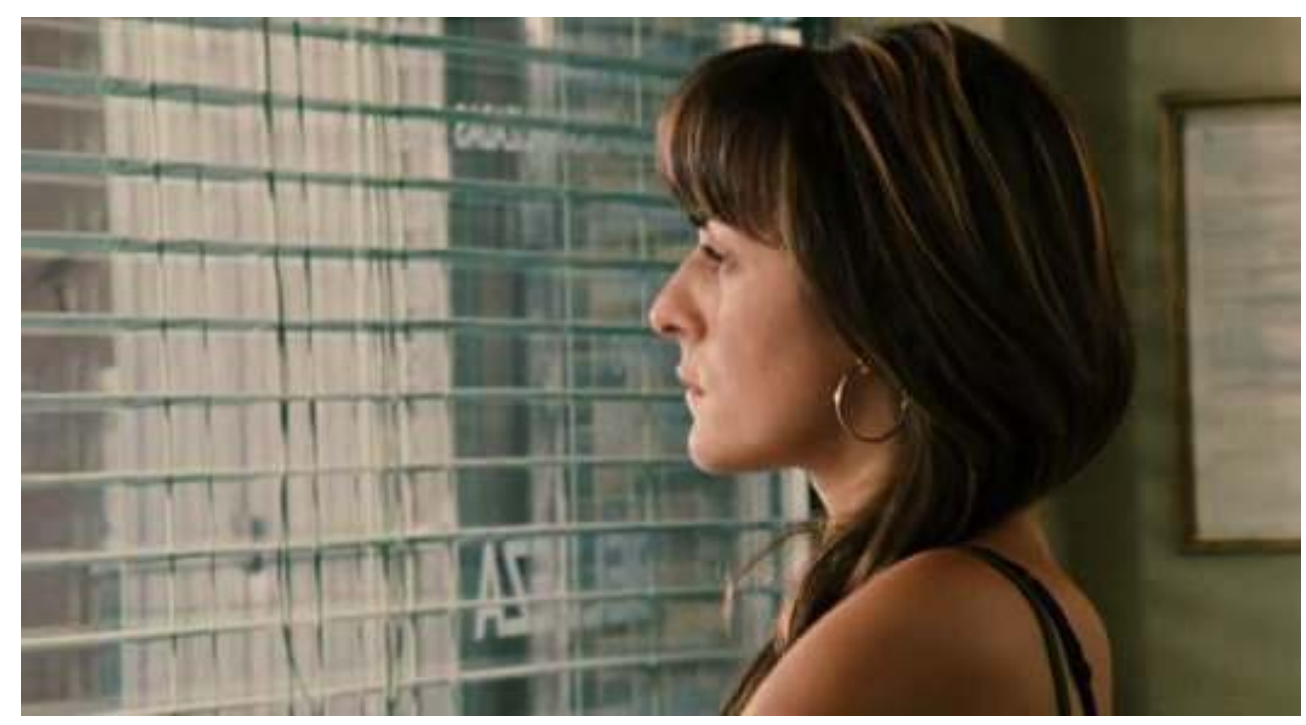

Esta frontera de cristal será, de hecho, la última barrera que Zulema logre atravesar ${ }^{42}$. En la última parte de la película (1:22:40), un primer plano se cierne, de nuevo desde el interior, sobre el ventanal donde podemos leer invertido un cartel que reza: «Exóticas 
trenzas africanas, $60 €$ ». Gloria, que anteriormente había calificado las trenzas africanas de antihigiénicas ${ }^{43}$, termina por aceptar/integrar en su oferta la moda de nuevas potenciales clientes... La cámara se instala finalmente en el interior y en la escena Zulema aparece perfectamente integrada también en el conjunto, peinando a Caren y saciando, no sin ironía, su curiosidad ${ }^{44}$.

El ventanal es símbolo, como decíamos, de esa frontera cultural que separa a los dos grupos de prostitutas; la frontera se transmuta al final, gana en porosidad, se vuelve pasaje en el que se inscribe, en forma de cartel «publicitario», la marca de lo híbrido de una sociedad que evoluciona, se abre, se deja «contagiar».

La última barrera queda así anulada, desdibujada, reduciendo la distancia entre el dentro y el afuera, entre los dos puntos de vista también, entre el yo (de las «autóctonas») y el otro (de las inmigrantes).

51 Esta apertura funciona como simbólo de una evolución de mentalidades sociales desde un concepto de identidad cultural determinista (y que separaba a los dos grupos al fijarlos, detenerlos, en la diferencia) hacia una idea más dinámica de intercambio, progresión, adaptación.

Si, por un lado, el ventanal de la peluquería se establece como frontera -espacial y simbólica- de valores que separan el exterior y el interior, lo familiar y lo extranjero, en un proceso de «territorialización» basado en el temor del otro, de su diferencia, es significativo, por otro lado, que la escena en la que Zulema entra por primera vez en este «territorio» comience mostrándonos ese mismo ventanal ocupado por un cartel publicitario, marca de una ruptura con los hábitos del pasado.

El mismo escaparate, símbolo de repliegue, de barrera, de muro detrás del que se ocultan los miedos, se transforma finalmente en frontera porosa, pasaje, vitrina-exhibición de un encuentro: «Exóticas trenzas africanas» en la luna del escaparate de una peluquería de barrio de Madrid es la prueba irrefutable de que «lo otro» se han instalado, efectivamente, en España, transformándola.

Dicha transformación, que acabamos de ver representada en la película a través del cambio operado en un espacio concreto, estrucutra la construcción narrativa del filme y hace de Princesas un llamamiento a la tolerancia, a la hospitalidad entendida esta primero como acto de acogida, de aceptación del «otro». Entendida así, la hospitalidad aparece primero, en este nivel del encuentro, como un acto en el que el otro sigue siendo, no obstante, individuo «ajeno» y elemento «exótico», curioso, pero Princesas va más allá.

\section{Umbrales, pasajes: del «otro ajeno» al «otro propio»}

Como hemos adelantado anteriormente, el «milagro» de esta transformación lo hace posible el personaje de Caye, vecina de Zulema, desde cuyo punto de vista se articula el encuentro. La curiosidad de Caye, por un lado y el incidente del cliente «robado» por otro ${ }^{45}$, van a llevarla a acercarse progresivamente a Zulema.

Este progresivo acercamiento, que va a reunir a las dos rivales hasta convertirlas en amigas, se nos muestra antes que contársenos.

El trayecto que Caye recorre para acercarse a Zulema es un camino simbólico de ascensión moral, iniciático, podemos decir, que se traduce visualmente en la película en 
forma de traspaso de umbrales, como una forma de renunciar al discurso y dejarnos ver las cosas ahí dónde y cómo suceden.

Son numerosísimos los planos, escenas, secuencias donde los personajes aparecen enmarcados por una puerta, entrando y saliendo, recorriendo un pasillo, mirando por una ventana... Los vidrios y ventanales (de los que la luna de la peluquería es solo un ejemplo, el más significativo, pero no el único) son a veces una forma de pudor, una excusa para dejarnos fuera de la intimidad de los personajes y mantenernos a distancia, subrayando así nuestra posición de espectador, de testigo externo de los acontecimientos. Las puertas, en cambio, son umbrales que debemos atravesar con ellos para avanzar, no solo en la fábula, sino en su proceso emocional de la hostilidad a la hospitalidad.

Así sucede con la secuencia del primer encuentro efectivo entre Caye y Zulema.

Recordemos que Caye había visto ya por la ventana del patio la ropa tendida de Zulema (su camiseta "69 Sexy girl» primer indicio de su presencia), ha reconocido (a través de la luna del bar) la camiseta en la chica que le ha robado el cliente del bar, ha recibido los 10 euros de Zulema, hasta entonces ese otro extranjero y extraño que Caye sentía como amenaza, y que ahora comienza a intrigarla. La secuencia que vamos a analizar empieza (16:20) en el piso de Cayetana, con un plano de las manos de Caye contando el dinero acumulado, se oye a lo lejos una música demasiado alta. Caye empieza a ponerse nerviosa, se levanta, abre la ventana, ve las cortinas abiertas de Zulema y la llama «¿joye!?» (16:43). Decidida (y visiblemente enfadada), se dirige hacia la puerta (plano dorsal) y la traspasa; reencuadre, la cámara la muestra ahora caminando por el pasillo que lleva a la escalera del edificio (plano a la altura del pecho), la cámara la espera y sigue su movimiento, Caye pasa delante dejando atrás la cámara que, en ligero contrapicado la encuadra de nuevo de espaldas, subiendo la escalera; nuevo cambio de plano, la cámara la muestra ahora en contrapicado subiendo (un hombre se cruza con ella pero Caye no le presta atención); llega delante de la puerta, semiabierta, se detiene delante (plano dorsal y perfil: 17:00), mira, llama; nuevo encuadre: desde el interior percibimos el rostro de Caye en el hueco de la puerta entreabierta; despacio Caye abre la puerta y entra (nuevo plano dorsal) y por fin atraviesa el umbral (nuevo encuadre frontal). Caye llama: «¿hola?» (17:19). A partir de este momento se suceden una serie de planos (en cámara subjetiva, semisubjetiva, primeros planos del personaje que mira en torno suyo...) que nos introducen en la intimidad del piso de Zulema hasta la televisión - de donde procede la música alta que veníamos escuchando-; Caye baja el volumen del televisor y en ese momento se escucha el sonido de un objeto que cae en un cuarto contiguo. Caye se da vuelta (encuadre de espaldas). Caye, desenfocada, en el fondo, la cocina nítida, y una nueva puerta, un nuevo umbral que atravesar (17:54); nueva sucesión de primeros planos de Cayetana (de frente, de espaldas) mientras avanza, cámaras subjetivas que encuadran una taza rota en el suelo, una cuchara y otros objetos, indicios de una pelea, hasta llegar (con una panorámica ascendente) a un primer plano de Zulema (a la altura del pecho) en el suelo de la ducha, con signos de violencia sobre su brazo y cara; primer plano de Caye que la mira y cruza la mirada de Zulema, que al verla aparta la mirada; nuevo primer plano de Caye con la mirada fija en Zulema, desconcertada.

Después de esta secuencia, las dos chicas se encuentran en el hospital donde Caye ha acompañado a Zulema para hacerse una radiografía y otras pruebas. En el pasillo donde esperan, como en un lugar en tránsito, un poco entre la hostilidad pasada y la amistad que les unirá de ahora en adelante, conversan por primera vez. 
62 A partir de este momento una serie de secuencias que alternan fondo musical (Manu Chao) y conversaciones animadas o intimistas nos muestra a las chicas charlando, compartiendo, intercambiando, conociéndose. El mercadillo, el Rincón Latino, su piso, son los espacios que Zulema abre para Caye; su piso, su familia, sus deseos y esperanzas, son los espacios que, por su parte, Caye abre a Zulema. Todo su universo, salvo, como vimos, el de la peluquería que será el último espacio que Caye, por miedo, por cobardía, por indecisión, le deje atravesar.

63 A través entonces de la mostración de estos pasajes, umbrales, fronteras, que nosotros espectadores seguimos y atravesamos con Caye ${ }^{46}$, el filme plantea una evolución hacia el encuentro con el otro que es primero apertura, acogida del otro en tanto ajeno y diferente (como veíamos en el apartado precedente) pero también, en un sentido más profundo del encuentro, comprehensión del otro en uno mismo, en el reconocimiento de nuestra propia otredad y por lo tanto en una implicación de lo ajeno como propio.

64 La relación que llegarán a compartir las dos mujes funciona así como paradigma de ese encuentro con lo propio a través del otro: la visión del otro es proceso de aceptación del carácter heteróclito de uno mismo. Es ahí donde la hospitalidad supera la mera caridad y se convierte en posibilidad de transformación, enriquecimiento de uno mismo.

Accueillir ne signifie pas simplement prendre soin d'une vie fragilisée mais également accueillir ce qui, chez quelqu'un d'autre, ne se laisse pas reconduire à la structure narrative de soi. Je n'accueille jamais une subjectivité neutralisée mais toujours des histoires, récits, des voix discordantes. Ainsi le soi de l'accueillant n'est-il jamais assuré de garder sa voix intacte quand il fait entrer l'autre voix chez lui. C'est cette porosité des frontières qui donne sens, par-delà les frontières établies, à la possibilité de l'hospitalité ${ }^{47}$.

65 Este encuentro con uno mismo a través del otro (Caye se indigna con la violencia que Zule sufre en un proceso empático progresivo que la empuja a acercarse a ella pero también a encontrarse con ella misma, como hemos visto) aparece representado en el universo visual -antes que discursivo- de Princesas a través de recorridos que, como el que hemos analizado, nos llevan por los distintos umbrales y pasos desde el espacio de la hostilidad al de la hospitalidad. Esta hospitalidad que, como explica el texto citado, no nos deja intactos.

\section{El último umbral: del fueracampo al otro campo}

66 Decíamos al principio del análisis que, a pesar de que Zulema puede ser considerada heroina de la fábula, en cierto sentido el punto de vista de la diégesis se sitúa claramente del lado de la mirada de Cayetana: es Cayetana quien nos abre las puertas, tanto de forma simbólica como visual -tal y como analizamos supra - a la existencia de Zulema y por tanto a la trama central y planteamiento ético principal de la película.

67 Efectivamente el «descubrimiento» de Zulema (nuestro descubrimiento) se lleva a cabo a través de los ojos de Caye. Durante aproximadamente los primeros veinte minutos del filme, Zulema permanece relegada al fueracampo y es a través de la mirada de Caye como nos acercamos a ella, hasta que Zulema pasa progresivamente a ocupar el «campo». 


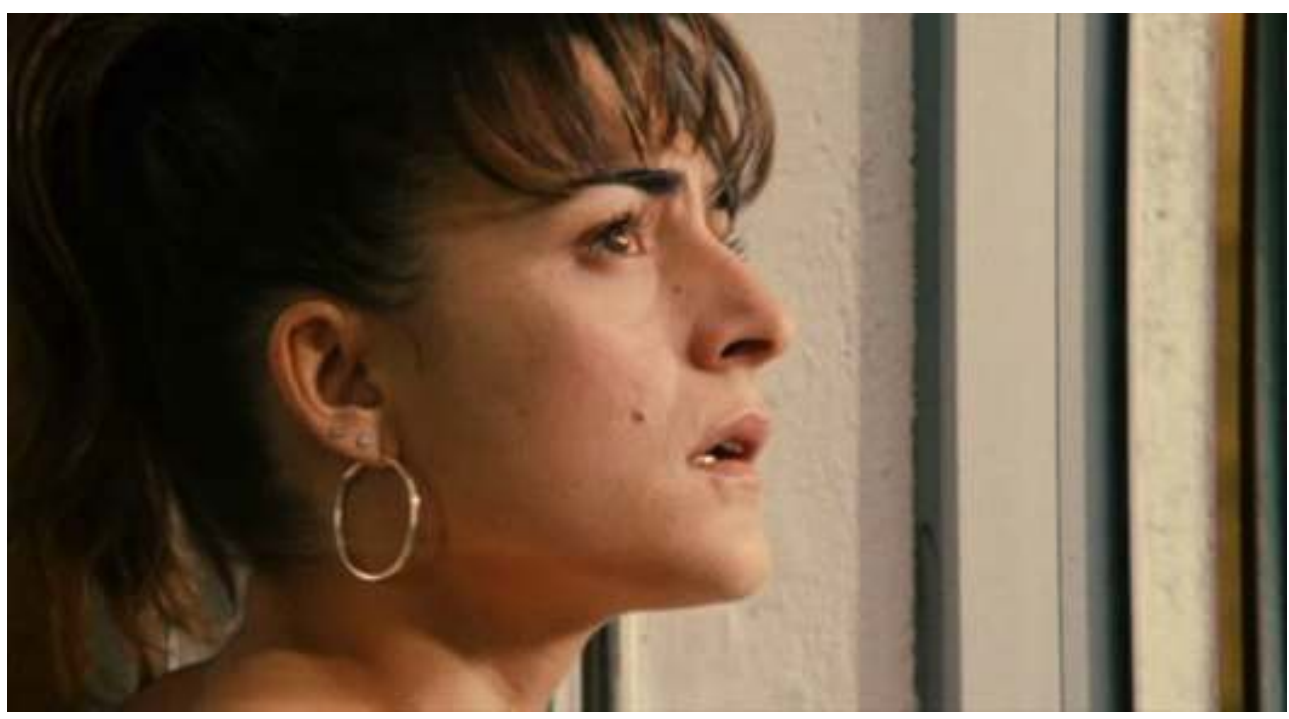

En esta primera parte de la película, ese juego que se establece entre el campo y el fueracampo logra crear una tensión en donde el otro es también (como, desde un punto de vista discursivo, en las escenas de la peluquería por ejemplo) un ausente/presente: amenaza o fuente de curiosidad. La intriga de la película se articula, de este modo, en torno a este espacio fílmico que opone visual y simbólicamente los dos campos $\mathrm{y}$, por ende, a las dos protagonistas (o mejor dicho a Caye contra la otra del fueracampo que es Zulema).

El juego de miradas que se establece con el fueracampo supone también una ruptura (una «apertura») con respecto a esta espacialidad delimitada de los planos en que Caye se nos muestra enmarcada (por puertas, ventanas... recordemos por ejemplo los planos de la secuencia analizada en el apartado anterior), encerrada, símbolo tal vez de la rigidez inicial de su pensamiento.

70 Si en el espacio de frontera que es la peluquería, la película nos invitaba a participar en tanto testigo privilegiado de los acontecimientos, manteniéndonos no obstante a una distancia higiénica adecuada, al situarnos en este punto de vista que es la mirada de Caye, con la que atravesamos umbrales y recorremos la distancia que nos separa del otro, la película nos conduce asimismo al terreno, algo menos aséptico, de la empatía.

71 Podemos ahondar no obstante y proponer un tercer nivel de implicación del espectador. En efecto, el filme sugiere aún un último espacio donde el espectador cobra su auténtico protagonismo, esto es, el espacio de la reflexión. El espacio cinematográfico que el filme crea es un espacio hospitalario que acoge, también, al espectador al invitarle a atravesar un último umbral: la frontera de la pantalla cinematográfica operando así una última ruptura, la de la frontera entre la ficción y la realidad.

72 Una vez que Caye ha entrado en contacto con Zule y que ambas entablan amistad, es en las escenas de sus diálogos donde, a tavés de un juego campo/contracampo/fueracampo, León de Aranoa logra crear un espacio fílmico en que la intimidad entre las dos amigas irá tomando cuerpo y densidad, hasta llegar a ese momento final en que una y otra hacen depender su existencia de la existencia del otro (de la otra). Gracias a la creación de este espacio fílmico íntimo los espectadores asistimos también a esa evolución en la que el otro se vuelve comprehensible e indisociable de la propia existencia ${ }^{48}$.

73 El juego de miradas campo/fueracampo no está, en efecto, exento de una significativa interpelación a ese que mira desde el espacio del otro campo $^{49}$, esto es, a nosotros 
espectadores, al involucrarnos e invitarnos a compartir los principios por los que la película aboga.

74 Son varias las secuencias que podríamos analizar para ilustrar nuestro razonamiento pero quizás la más significativa sea la que se sitúa entre los minutos 26:28 y 30:00 de la película. Zulema y Caye conversan sentadas a una mesa del Rincón latino.

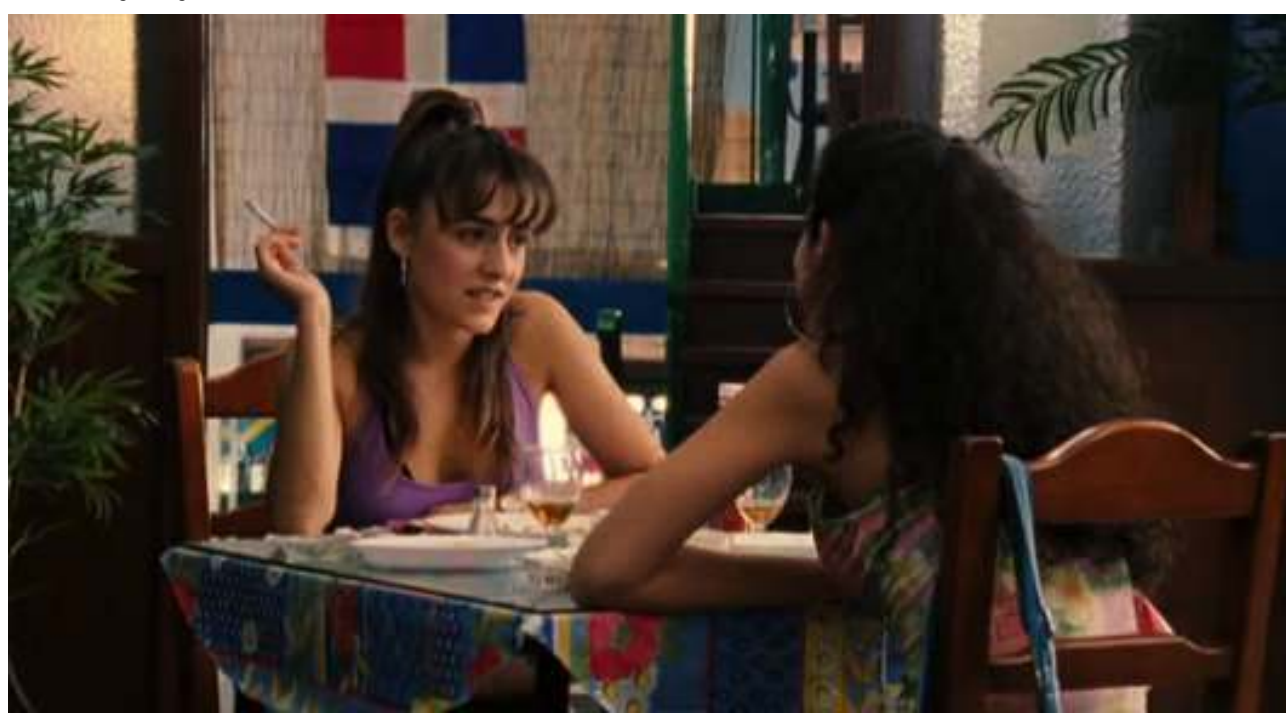

conversación va tomando un tono cada vez más intimo $\mathrm{y}$, paralelamente, como subrayando esta progresión hacia la intimidad, el encuadre se va cerrando hasta colocarnos en una situación de acercamiento intimista con los personajes. Otro detalle: el juego campo/contracampo que se instala prácticamente desde el inicio de la conversación y que incluye primero a uno de los dos personajes en escorzo, se va cerrando progresivamente hacia un encuadre de planos a la altura de los hombros y primeros planos donde sucesivamente el espectador «mira» a una $u$ otra interlocutora. Mediante este juego de miradas en el que se nos implica «físicamente» se crea una sensación de estar ahí sentados a la mesa, marcando así una presencia que se substituye a la propia presencia de la cámara con la que nos identificamos.

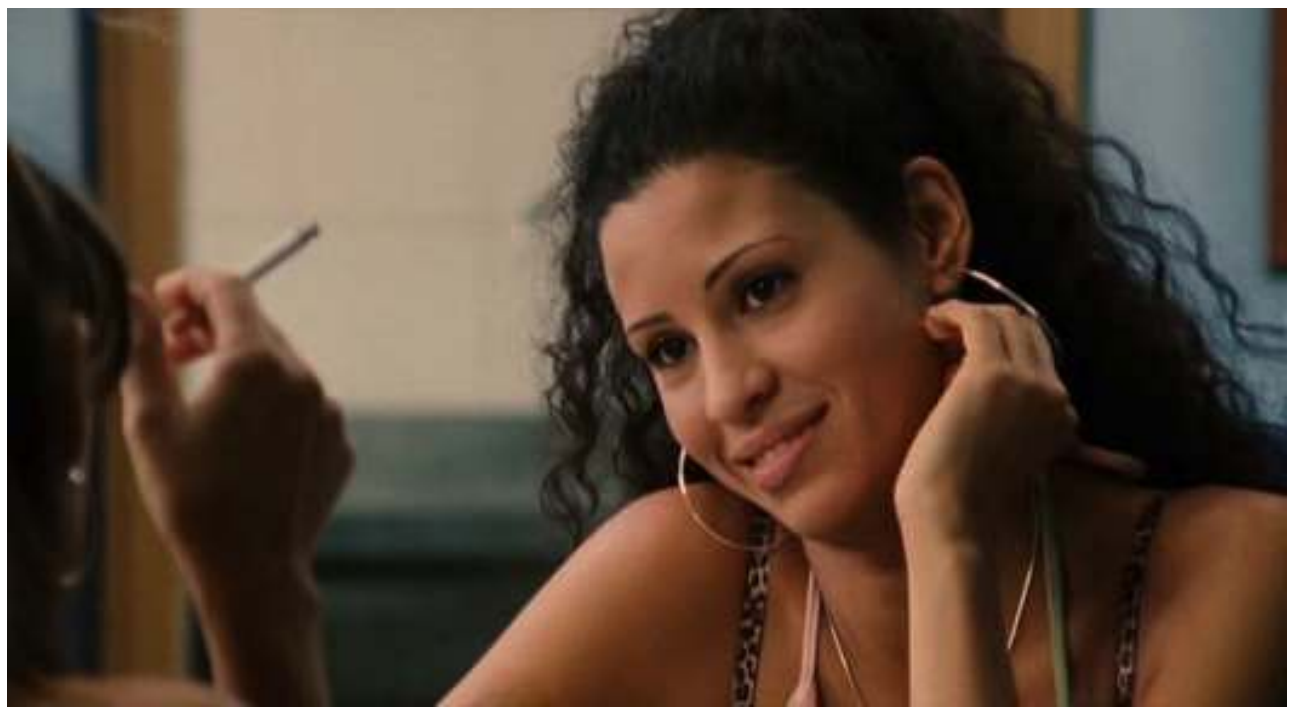

76 Si los planos de los personajes nos acercan por un lado al rostro como exterioridad del ser pero también espacio donde se opera el reconocimiento del otro, el juego de miradas entre los personajes y de los personajes con su entorno (campo/contracampo/ 
fueracampo) crea un sistema visual que nos instala en ese espacio de la intimidad, de acercamiento, de encuentro.

La opción plástica del universo visual del filme que venimos comentando (naturalidad iluminación-, fluidez -movimientos de cámara-, planos medios cortos, primeros planos, etc.) contiene una función que es en primera instancia emotiva (conseguir la empatía con los personajes) pero también discursiva: es una manera, en definitiva, de implicarnos en el cuestionamiento ético sugerido (aunque no explícito) de nuestra propia posición frente a la otredad. Al situarnos en el punto de vista del «hombre de la cámara» ${ }^{50}$ , la instancia narrativa nos enuncia además la cercanía, nos la «impone» como respuesta al conflicto.

Una última figura redunda en la interpelación al espectador en la escena final de la película: la figura de la mirada a la cámara, que es la manera con que el espectador es explícitamente invitado a franquear la frontera cinematográfica de la pantalla. La cámara nos muestra un primer plano de Cayetana (a la altura de los hombros) la cabeza ligeramente ladeada, la mirada hacia abajo, iluminada por la luz que entra por la ventana, pensativa, (1:44:44), oímos el sonido del teléfono procedente del comedor, corte, reencuadre... Caye de espaldas, gira lentamente la cabeza, su madre la llama «¿Caye?»; (silencio), ¡Caye, tu teléfono! (Caye se gira y mira a la cámara), suena de nuevo el teléfono «iCaye!» ligero reencuadre/zoom, su mirada se dirige de nuevo hacia el fueracampo (la voz de su madre en el comedor), sus ojos buscan la voz «¡Coge tú, mamá!», silencio. Caye se muerde los labios, los ojos humedecidos y mira al vacío.

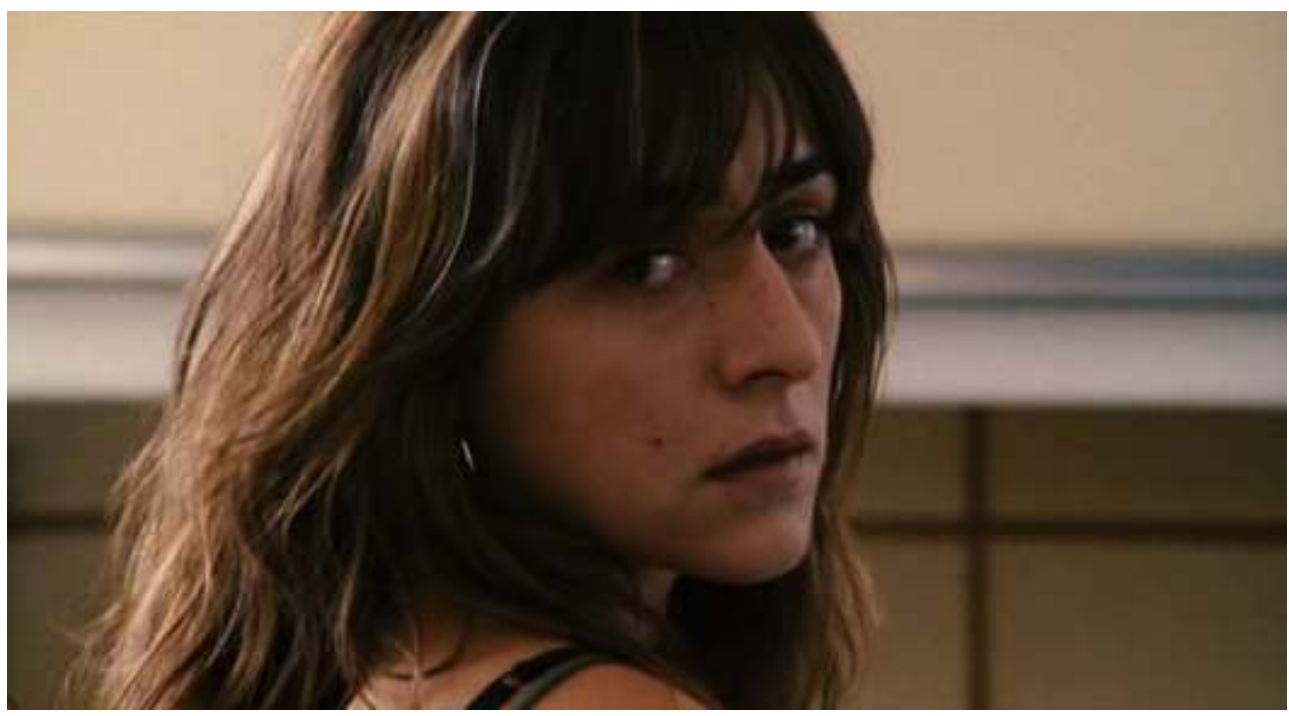

Con esta mirada, breve pero intensa, que Caye nos dirige, la película parece cuestionarnos en nuestra posición de testigos pasivos para incomodarnos: ya no podemos ver sin ser vistos...

De alguna manera no podremos ahora limitarnos a salir de la sala oscura e ignorar que detrás del buen momento que este «cuento maravilloso sui generis» nos ofrece, la película nos propone un «algo más» que nos corresponde ahora a nosotros, espectadores «del otro lado del espejo», interrogar.

81 En este cuento sin príncipes $^{51} \mathrm{ni}$ «final feliz» la «moraleja» es tal vez que la vida es eso, mirar de frente, asumir sus límites, seguir el camino y coger a tiempo los desvíos (1:18:54): 
Hay un día - dice Caye-, ya verás, un día que es la hostia. Ese día todo es bueno [...] y todo lo que te pasa ese día es todo lo que quieres que te pase [...] pasa solo una vez en la vida, por eso hay que estar muy atenta, no sea que se te pase. Es como un desvío, como cuando vas por la carretera y hay un desvío hacia otro sitio, pero a lo mejor vas hablando por el móvil o estás discutiendo pensando en lo que sea y no te das cuenta y se te pasa, te jodiste, porque ya no puedes volver atrás... pues ese día es lo mismo, un desvío y es muy importante porque puedes elegir por donde va a seguir todo, si por ese camino que es nuevo o no, por eso tenemos que estar muy atentas Zule, muy atentas, porque hay muy pocas cosas buenas y si encima se te pasan porque estás hablando por el móvil o pensando en otra cosa sería una mierda, una mierda completa.

El filme Princesas se presenta, de este modo, como un entramado en el que, desde la narración, con la inversión del esquema de cuento maravilloso, hasta el sistema visual desplegado, el realizador pone en obra un universo fílmico que busca implicarnos en el cuestionamiento ético que subyace a la historia, invitándonos, en última instancia, a la reflexión y orientándonos hacia un posicionamiento favorable al encuentro con el otro, con la otredad.

Para conseguir este objetivo Aranoa nos invita a atravesar hasta anularlas diferentes fronteras físicas, simbólicas y discursivas llevándonos desde una posición objetivada en el punto de vista del «autóctono» enfrentado a un «otro ajeno», hasta el acercamiento empático con ese «otro propio», a través de la identificación con la mirada de Cayetana, para finalizar con un tercer nivel de implicación en el sistema visual fílmico que es invitación a la reflexión y solicitación a un posicionamiento personal en tanto espectadores implicados por y en nuestro entorno.

En definitiva, si bien Princesas comparte con otras películas sobre inmigración la exploración de posturas «nacionalistas» (rechazo al inmigrante según una concepción del territorio anclado en un pasado tradicionalista de corte proteccionista e incluso reaccionario), el filme Princesas parece ir más allá al proponer una visión del mundo donde triunfarían valores universales e igualitarios entre los seres humanos según una lógica globalizadora para la que todo individuo, más allá de diferencias culturales, sociales y por supuesto de origen, aspira o tiene derecho a aspirar a lo mismo. Por otro lado, si Princesas parte de los mismos plateamientos que las primeras películas en torno a la inmigración vista como problema: estereotipos, prejuicios, rechazo del emigrante como amenaza en lo laboral, actitud proteccionista de los «nacionales», atrincheramiento frente al temor por la destrucción de valores propios, etc., el filme sugiere una superación de fronteras en ese encuentro con la otredad que significa el compartir miserias pero también sueños y esperanzas comunes.

De este modo, Princesas, en los preámbulos de lo que se ha llamado la transición multicultural española ${ }^{52}$, se situaría en una posición discursiva postnacional (según el concepto de Habermas que explicamos en la introducción de nuestro artículo). En Princesas no se trata tanto de un mensaje de tolerancia hacia el otro y su diferencia, sino más bien del planteamiento de un principio no jerárquico (que anula la relación víctimaverdugo, «acogiente» y acogido) según el cual todos somos «otros», planteando una apología del multiculturalismo en el que el otro no sería ya un ajeno a acoger con generosidad (mirada finalmente «narcisista» de nuestro encuentro con el otro) sino un otro propio, un «otro como uno mismo» ${ }^{53}$, mi semejante, mi hermano, como diría el poeta... 
cesas, por último, nos invita, en la creación de un espacio cinematográfico favorable a la hospitalidad, a superar la ecuación inmigración = problema a través de un encuentro con el otro que no podrá dejarnos, a nosotros espectadores, intactos.

\section{BIBLIOGRAFÍA}

AGRELA ROMERO Belén, «De fundamentalismos institucionales y discursos culturalistas. La construcción de otredades en la política de inmigración española», in F. Javier García Castaño y Carolina Muriel López (eds), La inmigración en España, contextos y alternativas, $3^{\text {er }}$ Congreso, Universidad de Granada, 2002, vol. II, pp. 407-420.

ARANGO VILA-BELDA Joaquín, «La migración en España a comienzos del siglo XXI: un intento de caracterización», in F. Javier García Castaño y Carolina Muriel López (eds), La inmigración en España, contextos y alternativas, $3^{\text {er }}$ Congreso, Universidad de Granada, 2002, vol. II, pp. 57-69. AUMONT Jacques, «Vertov et la vue», Cinémas et réalités, CIEREC, Université de Saint- Étienne, 1984, pp. 23-44.

AUMONT Jacques y MARIE Michel, Análisis del film, Barcelona, Paidós comunicación, 1993, 311 pp. BLANCo Cristina, Las migraciones contemporáneas, Madrid, Alianza editorial, 2000.

BURKHARD Pohl y TÜRSCHMANN Jörg (eds), Miradas glocales. Cine español en el cambio de milenio, Frankfort/Madrid, Vervuerz/Iberoamericana, 2007.

CASTIELlo Chema, Los parias de la tierra: inmigrantes en el cine español, Madrid, Talasa, 2005.

CHECA OLMOS Francisco, «España y sus inmigrados. Imágenes y estereotipos de la exclusión social», in F. Javier García Castaño y Carolina Muriel López (eds), La inmigración en España, contextos y alternativas, $3^{\text {er }}$ Congreso, Universidad de Granada, 2002, vol. II, p. 421-436.

FOUCHER Michel, L'obsession des frontières, Perrin, 2007.

FUSI Juan Pablo, La evolución de la identidad nacional, Madrid, Temas de Hoy, 2000.

GARCIA CASTAÑo F. Javier y MURIEL LOPEZ Carolina (eds), La inmigración en España, contextos y alternativas, $3^{\text {er }}$ Congreso, Universidad de Granada, 2002, vol. I y II.

GOYTISOLO Juan y NAÏR Sami, El peaje de la vida: Integración y rechazo de la emigración en España, Madrid, Aguilar, 2000.

HABERMAS Jurgen, Après l'État-nation, une nouvelle constellation politique, Fayard, 2000.

IGARTUA Juan José, HUMANES María Luisa, MUÑIz Carlos, CHENG Lifen, MELLADo Claudia, MEDINA Eudomary y ERAzO María de los Ángeles, «La información sobre inmigración e inmigrantes en la prensa española. ¿Barreras mediáticas a la integración o imágenes que generan xenofobia?», Comunicación y Diversidad Cultural, Forum 2004, Barcelona, 24 al 27 de mayo de 2004, consultable en <www.portalcomunicacion.com/dialeg/paper/pdf/110_igartua.pdf>.

La inmigración en Canarias. Contexto, tendencias y retos, Fundación Pedro García Cabrera, 2007. 
LE BLANC Guillaume, «Politiques de l'hospitalité», in Yves Charles Zarka (ed.), «Immigration : fantasmes et réalités», Cités, n. ${ }^{\circ} 46$, Paris, 2011.

LOPEZ Ana María, «La política española de inmigración en las dos últimas décadas. Del asombro migratorio a la política en frontera y la integración», in La inmigración en Canarias. Contexto, tendencias y retos, Fundación Pedro García Cabrera, 2007, pp. 23-37. Artículo consultable en línea: <http://digital.csic.es/handle/10261/11920>.

MALO DE MOLINA José Luis, Una larga fase de expansión de la economía española, Madrid, publicaciones del Banco de España, Documentos ocasionales, $n .^{\circ} 0505,2005$. Consultable en línea: <www.bde.es/ $\mathrm{f} /$ webbde/SES/Secciones/Publicaciones/PublicacionesSeriadas/DocumentosOcasionales/05/Fic/ do0505.pdf>.

METZ Christian, L'Énonciation impersonnelle ou le site du film, Paris, Klincksieck, 1991.

MONTERDE José Enrique, El sueño de Europa, cine y migraciones desde el Sur, Junta de Andalucía, Consejería de cultura, Filmoteca de Andalucía, 2008.

MORENO FUENTES Francisco y BRUQUETAS CALLEJo María, Inmigración y Estado de Bienestar en España, Obra social de La Caixa, Colección Estudios Sociales, n. ${ }^{\circ}$ 31, 2011.

MOYANO Eduardo, La memoria escondida: emigración y cine, Madrid, Tabla rasa, 2005.

OUDART Jean-Pierre, «La suture», Cahiers du cinéma, n. ${ }^{\circ}$ 211-212, abril-mayo 1969, consultable en línea: <www.fichier-pdf.fr/2012/11/23/oudart/oudart.pdf>.

SANTAOLALLA Isabel, Los «otros»: etnicidad y «raza» en el cine español contemporáneo, Prensas Universitarias de Zaragoza, 2005.

SEQUEN MONCHEZ Alexander, El cálculo egoista: inmigración y racismo en la España del siglo XXI, Madrid, Ed. Trotta, 2010

ZARKA Yves Charles (ed.), «Immigration : fantasmes et réalités», Cités, n. ${ }^{\circ}$ 46, Paris, 2011.

Enlaces web consultados (última comprobación: 29/01/2013)

Especial El Mundo: <www.elmundo.es/especiales/2005/02/sociedad/inmigracion/index.html>.

Especial El País: <http://elpais.com/diario/2008/07/06/eps/1215325611_850215.html>.

Instituto Nacional de Estadística: <www.ine.es/inebmenu/mnu_migrac.htm>.

Observatorio Permanente de la inmigración: <http://extranjeros.empleo.gob.es/es/

ObservatorioPermanenteInmigracion/>.

Secretaría General de Emigración e inmigración (rúbrica «Normativa y jurisprudencia»): <http:// extranjeros.empleo.gob.es/es/index.html>.

\section{NOTAS}

1. Para una información más exhaustiva se pueden consultar los datos recogidos en las páginas del Instituto Nacional de Estadística <www.ine.es/inebmenu/mnu_migrac.htm> y del Observatorio Permanente de la inmigración <http://extranjeros.empleo.gob.es/es/ ObservatorioPermanenteInmigracion/> donde se pueden comprobar los datos de la evolución de la población española según diferentes criterios. 
2. No son pocas las publicaciones que sobre el tema de la inmigración han salido a la luz en los últimos años. Asimismo la inmigración ha sido objeto de coloquios y encuentros, tesis doctorales, etc. dando cuenta de un interés científico creciente. Valgan como ejemplo las siguientes referencias: C. Blanco, Las migraciones contemporáneas, Madrid, Alianza editorial, 2000; F. J. García Castaño y C. Muriel López (eds), La inmigración en España, contextos y alternativas, $3^{\text {er }}$ Congreso, Universidad de Granada, 2002, vol. I y II. La inmigración en Canarias. Contexto, tendencias y retos, Fundación Pedro García Cabrera, 2007; J. Goytisolo y S. Naïr, El peaje de la vida: Integración y rechazo de la emigración en España, Madrid, Aguilar, 2000; A. Sequén Mónchez, El cálculo egoista: inmigración y racismo en la España del siglo XXI, Madrid, Ed.Trotta, 2010, o aún, F. Moreno Fuentes y M. Bruquetas Callejo, Inmigración y Estado de Bienestar en España, Obra social de La Caixa, Colección Estudios Sociales, $\mathrm{n} .^{\circ} 31,2011$.

3. De «asombro migratorio» califica esta reacción inicial A. M. López en su artículo «La política española de inmigración en las dos últimas décadas. Del asombro migratorio a la política en frontera y la integración», in Inmigración en Canarias, op. cit., pp. 23-37. Artículo consultable en línea: <http://digital.csic.es/handle/10261/11920>.

4. Se puede consultar de manera, otra vez, más detallada y exhaustiva la información recogida en la página de la Secretaría General de Emigración e inmigración (rúbrica «Normativa y jurisprudencia»): <http://extranjeros.empleo.gob.es/es/index.html>.

5. O no porque en el marco de esta «reflexión» se han generado también proyectos como las ayudas al «retorno voluntario de inmigrantes» que se aplican desde 2007.

6. A la vez que se diseña la política de inmigración, se refuerzan los lazos en cooperación, se favorece la acogida de grupos más fácilmente «asimilables» como los latinoamericanos, se crean (1993) la Dirección General de Migraciones (integrado en el Ministerio de Asuntos Sociales), se establece el Plan para la integración social de los inmigrantes con la creación de un Observatorio Permanente de la Inmigración(1994), etc. Cfr. C. Blanco, Las migraciones contemporáneas, op. cit., pp. 164 y ss.

7. Delincuentes, ilegales, prostitutas... es a menudo la «imagen» que de los inmigrantes se crea en el espacio mediático que les otorgan diarios y medios de comunicación en general. La prensa, tal y como nos explica C. Blanco (op. cit., p. 175) es una de las fuentes prioritarias en la formación de opinión y la creación de una imagen que influye en la percepción que el ciudadano tiene del inmigrante. Así, al estudiar al conjunto de creencias y opiniones en torno a la inmigración, Blanco observa una tendencia al estereotipo y a opiniones arbitrarias e inexactas alimentadas o favorecidas por la imagen vehiculada en las noticias, a menudo sensacionalistas, que los media recogen. El concepto de inmigrante se asimila, de este modo, a pobreza o ilegalidad, e implica una connotación negativa (inmigrante es el «moro», el «sudaca», el «chino»... no el holandés o el americano, que es, «tan solo», un extranjero). A este respecto véanse por ejemplo F. Checa Olmos, «España y sus inmigrados. Imágenes y estereotipos de la exclusión social», in F. J. García Castaño y C. Muriel López, La inmigración en España, contextos y alternativas, op. cit., p. 421; o también la comunicación que un grupo de investigadores de las Universidades de Salamanca y Juan Carlos I presentaron en Comunicación y Diversidad Cultural, Forum 2004, Barcelona, del 24 al 27 de mayo de 2004: J. J. Igartua, M. L. Humanes, C. Muñiz, L. Cheng, C. Mellado, E. Medina y M. de los Ángeles Erazo, «La información sobre inmigración e inmigrantes en la prensa española. ¿Barreras mediáticas a la integración o imágenes que generan xenofobia?», consultable en < www.portalcomunicacion.com/dialeg/paper/pdf/110_igartua.pdf>.

8. <www.elmundo.es/especiales/2005/02/sociedad/inmigracion/index.html>.

9. <http://elpais.com/diario/2008/07/06/eps/1215325611_850215.html>.

10. Las migraciones contemporáneas, Madrid, Alianza editorial, 2000, p. 9.

11. Dedicado al devenir del Estado nacional en el contexto de la globalización, fue publicado en Francia bajo el título Après l'État-nation, une nouvelle constellation politique, Fayard, 2000. Como reza el prefacio, la versión francesa añade a las dos partes de la publicación alemana, una tercera 
parte titulada «L'État-nation européen sous la pression de la mondialisation» que apareciera en Blätter für Deustche und Internationale Politik, n. ${ }^{\circ} 4,1999$ bajo el título de «Der europaïsche Nationalestaat unter dem Druck der Globalisierung». El estudio parte de un interrogante que plantea la conservación (y universalización) de la democracia propia al Estado social más allá de las fronteras nacionales.

12. Hay que decir que entre ambas publicaciones tuvo lugar el acontecimiento axial del 11 de septiembre en Nueva York o, aún más determinante para nuestro país, del 11 de marzo madrileño. Ambos acontecimientos dieron un nuevo impulso al control fronterizo, en España, la obsesión de la frontera (y una de sus implicaciones directas, la «inmigración preferente», es decir la acogida privilegiada de comunidades que se juzgan menos peligrosas, más fácilmente asimilables) parece estar relacionada directamente con la obsesión por la seguridad. Cfr. A. M. López Sala, «La política española de inmigración en las dos últimas décadas. Del asombro migratorio a la política en frontera y la integración», art. cit., p. 11.

13. Todas las traducciones de textos en francés en el original son mías.

14. M. Foucher, L'obsession des frontières, Perrin, 2007, p. 9.

15. Ibid., pp. 17-18.

16. Profesor de filosofía política en la Sorbona, autor entre otras numerosas publicaciones (algunas traducidas al español) de Repenser la démocratie, Paris, Armand Colin, $2010 \mathrm{y}$ fundador de la revista Cités.

17. «Immigration : fantasmes et réalités ", Cités, n. ${ }^{\circ} 46,2011$.

18. En La peur des barbares. Au délà du choc des civilisations (Paris, Robert Laffont, 2008) Tzvetan Todorov constata igualmente el hecho de que una serie de «pasiones sociales» agita las sociedades de hoy y destaca, inspirándose de la tipología propuesta por Dominique Moïsi («The Clash of Emotions, Foreing Affaires, 1-2, 2007), las pasiones de apetito (por participar de la repartición de la riqueza del mundo), resentimiento (hacia los antiguos colonizadores) miedo e indecisión (de la parte de los países receptores) (pp.15-116). Estas pasiones rigen las reacciones sociales que son reacciones basadas en constructos culturales que pertenecen al orden de la «imagen que la sociedad se hace de ella misma» y no en los hechos mismos (p. 91).

19. Y. C. Zarka, Repenser la démocratie, Paris, Armand Colin, 2010, p. 6.

20. La globalización y constitución de sociedades multiculturales suponen un «desafío» al orden democrático puesto que ponen a prueba la cohesión de las comunidades nacionales exigiendo la disociación entre cultura política y cultura mayoritaria. Esto supone la necesidad de asentar la solidaridad entre ciudadanos en una base más abstracta que la cultura mayoritaria, esto es, en lo que Habermas llama un «patriotismo constitucional». Es decir que la cultura política debe, en última instancia, disociarse de su anclaje en la nación y en la identidad nacional, entendidas estas como concepto homogeneizante, estático e inamovible y abrirse así hacia una idea más dinámica de pertenencias «en perpetua construcción de subculturas y de estilos de vida nuevos». Esta incorporación de lo híbrido y lo diverso de nuestras sociedades en nuestras políticas democráticas, no implica, sin embargo, la anulación/homogenización de las diferentes culturas, sino que, al contrario, la política de reconocimiento que el pensador alemán propone, deberá asegurar una coexistencia basada en la igualdad de derechos entre las formas de vida diferentes (comunidades étnicas, diferentes grupos lingüísticos, diferentes confesiones religiosas...) evitando así que la comunidad se descomponga en «subculturas aisladas unas de las otras» (J. Habermas, Après l'État-nation, une nouvelle constellation politique, op. cit., pp. 66-68).

21. B. Agrela Romero, «De fundamentalismos institucionales y discursos culturalistas. La construcción de otredades en la política de inmigración española», in F. J. García Castaño y C. Muriel López (eds), La inmigración en España, contextos y alternativas, $3^{\text {er }}$ Congreso, Universidad de Granada, 2002, vol. II, p. 412.

22. Sobre estos conceptos véase J. P. Fusi, La evolución de la identidad nacional, Madrid, Temas de Hoy, 2000. 
23. J. Arango Vila-Belda, «La migración en España a comienzos del siglo xxi: un intento de caracterización», in F. Javier García Castaño y Carolina Muriel López (eds), La inmigración en España, contextos y alternativas, $3^{\text {er }}$ Congreso, Universidad de Granada, 2002, vol. II, p. 67.

El deterioro, evidentemente, no puede más que confirmarse si lo miráramos desde el prisma de la crisis económica que desde 2008 afecta a España y que, aunque el tema excede el interés de nuestro estudio, ha determinado con seguridad nuevas transformaciones tanto en el fenómeno migratorio en sí como en su valoración.

24. Agradezco a su realizador, Fernando León, haberme permitido utilizar las imágenes que aparecen en el artículo para ilustrar mi reflexión.

25. Basten como ejemplo: C. Castiello, Los parias de la tierra: inmigrantes en el cine español, Madrid, Talasa, 2005; E. Moyano, La memoria escondida: emigración y cine, Madrid, Tabla rasa, 2005; I. Santaolalla, Los «otros»: etnicidad y «raza» en el cine español contemporáneo, Prensas Universitarias de Zaragoza, 2005 o aún, B. Pohl y J. Türschmann (eds), Miradas glocales. Cine español en el cambio de milenio, Frankfort/Madrid, Vervuerz/Iberoamericana, 2007.

26. Sin ánimo, evidentemente, exhaustivo. Sobre la historia de la representación del inmigrante/ extranjero en el cine español y la proliferación actual del «tema», con recuento detallado de producciones al respecto, véase I. Santaolalla, Los «otros»: etnicidad y «raza» en el cine español contemporáneo, op. cit. Igualmente una publicación que contiene un censo bastante completo de la filmografía/bibliografía del tema en el cine mundial (sobre todo europeo): J. E. Monterde, El sueño de Europa, cine y migraciones desde el Sur, Junta de Andalucía, Consejería de cultura, Filmoteca de Andalucía, 2008.

27. B. Pohl y J. Türschmann, Miradas glocales. Cine español en el cambio de milenio, op. cit., 2007, p. 20. 28. Resulta paradójico pensar que el progresivo rechazo del inmigrante y el inicio de procesos de «territorialización» coincidan en el tiempo con un período de auge económico: 2005 es considerado el año culminante de un periodo de expansión económica ininterrumpida de doce años y donde los flujos migratorios, desde un punto de vista puramente económico, eran considerados favorecedores de crecimiento tanto por el incremento poblacional que implicaban como por su participación activa en empleos rechazados por los nacionales... Cfr. a este respecto: J. L. Malo de Molina, Una larga fase de expansión de la economía española, Madrid, publicaciones del Banco de España, Documentos ocasionales, n. ${ }^{\circ}$ 0505, 2005. Según nota de la propia publicación, «Este texto desarrolla una conferencia pronunciada en el encuentro La economía española en la última década y su crecimiento potencial, dirigido por Julio Segura en los cursos de verano de la Universidad Complutense en San Lorenzo del Escorial en julio de 2005. En dicha sesión participaron también Carlos Solchaga y Fernando Eguidazu, y algunas de las controversias de aquel debate se han reflejado en este trabajo» (consultable en línea: <www.bde.es/f/webbde/SES/ Secciones/Publicaciones/PublicacionesSeriadas/DocumentosOcasionales/05/Fic/do0505.pdf $>$ ).

29. Transformación que sugiere una idea universal, abierta, de la otredad según una lógica igualitaria, como trataremos de explicar.

30. Se puede obtener toda la información técnica en la web oficial de la película: < www.redpixel.es/web/princesas/>.

31. Tras el título y un fundido en negro, (3:02) entramos en su piso, observamos sus objetos (un móvil de cristal con lunas y perlas, su mesita de noche, con el lubrificante, pañuelos desechables, un teléfono móvil que suena y la va sacando del sueño), y a Caye medio desnuda sobre su cama despertándose al ritmo de una de las canciones (sonido extradiegético) de Manu Chao de la banda musical del film (Cinco razones).

32. El primer ejemplo lo encontramos en el minuto 5:42 y señala este primer contraste entre el mundo «real» de Caye y su lado «maravilloso». El contexto es el siguiente: Caye está en la farmacia adquiriendo unos óvulos de pomada antimicótica, condones, etc., una madre entra en la farmacia con su hija, esta se sube a una báscula electrónica y Caye comenta: «cero kilos, ¡qué 
poquito! Eso es que eres un ángel»... La madre, para desconsuelo de Caye, se apresurará a aclarar: «es que hay que echarle monedas para que funcione».

33. Sin detenernos en los detalles, por falta de espacio, son varios los indicios que nos hacen afirmar esto: objetos como el móvil de cristal que sirve de puntuación en distintos momentos clave de la película, los peluches de su piso, o la escena en que tras un fracaso vuelve a su habitación en casa de la madre y duerme mientras esta última vela su sueño.

34. En 1928, en su Morfología del cuento, varias ediciones.

35. Esto aparece de forma explícita en el «texto» de la película (Zulema le explica a Caye su deseo de regresar para estar con su hijo (1:36:52) a lo que Caye le responde (1:37:00): «es normal, aquel es tu reino, Zule, y las princesas lejos de su reino no pueden vivir, son tan sensibles que se mueren de nostalgia [...] a mí a veces también me pasa».

36. El primer encuentro efectivo entre ambas se inicia con un conflicto; Caye llega tarde a una cita y se encuentra con que Zulema le ha «robado» el cliente. Caye enfurecida se dirige a ella y le dice (13:54): «Aquí hay unas normas, aquí no estás en la selva, que venís a este país y hacéis lo que os sale de los huevos.» Podemos considerar que desde este momento hasta que se hacen amigas, se plantea un reto para Zulema (y Caye también): el de ser aceptada como un ser humano, más allá de su condición de inmigante.

37. La «superación de la prueba» está representada por un primer gesto que va a facilitar el contacto entre ambas: después del conflicto Caye está en su casa, suena el timbre, abre la puerta y se encuentra con 10 euros (Zulema, de vuelta de su cita con el cliente que le ha robado a Caye, le deja la mitad de su ganancia, la comparte) (14:36).

38. Caye «sufre» de una especie de nostalgia anticipada (28:19): «¿es rara, no, la nostalgia?... Porque tener nostalgia en sí no es malo, eso es que te han pasado cosas buenas y las echas de menos. Yo por ejemplo no tengo nostalgia de nada porque nunca me ha pasado nada tan bueno como para echarlo de menos, eso sí que es una putada... ¿se podrá tener nostalgia de algo que aún no te ha pasado? Porque a mí a veces me pasa, me imagino cómo van a ser las cosas, los chicos, por ejemplo, o la vida en general y luego me da pena cuando me acuerdo de lo bonitas que iban a ser, porque iban a ser preciosas, en serio, preciosas, y luego cuando lo pienso me da nostalgia, porque iban a ser tan bonitas... Cuando me doy cuenta de que aún no han pasado y de que a lo mejor no pasarán nunca me pongo super triste, super triste tía... pero es como una tristeza a cuenta, como la fianza de cuando alquilas una casa, pero con tristeza... que la pones por delante, porque total sabes que la vas a acabar utilizando igual.» $\mathrm{O}$ aún, un poco más tarde (36:55): «A mí es lo que más me gustaría, trabajar en un despacho, de lo que sea, me da igual, pero que me vayan a buscar a la salida ¿te imaginas? Y verle esperando desde la ventana, que sea muy muy guapo y que se mueran todas de envidia... fíjate ya solo decirlo es la hostia, "ven a buscarme", el amor es eso ¿no? Que te vayan a buscar a la salida, el resto es todo una mierda, ni flores, ni anillos, por mí se lo pueden meter todo por el culo, pero que te vayan a buscar a la salida.»

39. El teléfono es su útil de trabajo, a través de él sus clientes entran en contacto; diversos planos detalles del teléfono le otorgan significados diferentes: el teléfono la despierta, el teléfono interrumpe las conversaciones familiares, el teléfono encierra el secreto que será desvelado.

40. Algo así como el ritmo de las canciones de Manu Chao de la banda musical del filme, esa especie de malegría, como el músico la denomina, que acompaña ciertos momentos de celebración en Princesas de las chicas de la calle (momentos en el mercadillo, en la casa de campo, el paseo en limusina final...) como una suerte de homenaje.

41. La mayoría de los diálogos, intensos en contenido o en emoción, se terminan casi siempre con un contrapunto humorístico manteniendo un equilibrio en la tensión del relato, desdramatizando la situación, haciéndola más «soportable».

42. Zulema no entrará en la peluquería hasta el final de la película. Incluso cuando la amistad entre Caye y Zulema parece consolidada, Caye mantiene esta relación en secreto para sus amigas, hasta el punto que, cuando Angela llama a la policía para que intervenga en una pelea ficticia, 
Caye no se atreve a ir a avisar a Zulema - que está en la plaza- y se sirve de «Metadona», una heroinómana que se pasea por el barrio como un fantasma. Esto significará un quiebre entre ambas, marcado también por un cambio de tono (a partir de aquí, los fundidos en negro acompasarán la caída al vacío de ambas -Zulema será violada y golpeada, Caye, fracasará en su relación con Manuel y se refugiará en su casa- hasta encontrarse ambas nuevamente en el hospital).

43. (1:01:42) Caye llega a la peluquería peinada con las trenzas que Zulema le había hecho, lo que le vale el calificativo de «traidora».

44. Escena también extremadamente divertida, donde Caren hace de nuevo gala de su «cultura» preguntando, entre otras cosas « ¿y se pasa mucho miedo en la patera?» «te entiende perfectamente Caren - le dice Cayetana- no hace falta que hagas gestos, y de América se viene en avión» (error que Caren justifica más tarde: «es que me he puesto nerviosa»).

45. Véase nota 36 y 37.

46. Esta sensación de acompañamiento de los personajes que otorga fluidez a los movimientos está favorecida por el uso de la steadicam que da a la película una impresión de naturalidad que abunda en la autenticidad (por no decir realismo) buscada en el tratamiento de los temas y de la imagen. Huelga decir que esta naturalidad forma parte de los recursos que el filme emplea para lograr el proceso de empatía del espectador con los personajes que comentamos más arriba.

47. G. Le Blanc, «Politiques de l'hospitalité», in Y.C. Zarka (ed.), «Immigration : fantasmes et réalités», Cités, n. ${ }^{\circ}$ 46, Paris, 2011, pp. 88-89.

48. Como expresa la protagonista en una de las últimas escenas (1:36:42): Caye le ofrece a Zule sus ahorros para que pueda volver a encontrarse con su hijo y a cambio le pide: «Acuérdate de mi, ¿vale? Existimos porque alguien piensa en nosotros y no al revés... no te olvides nunca.»

49. Por «otro campo» entiendo ese espacio o «campo ausente» donde se elabora la relación entre el sujeto-espectador y la instancia enunciadora del film, por un lado, y la relación entre un espectador que llamaremos «ideal» y el filme. Véase a este respecto: J. Aumont y M. Marie, Análisis del film, Paidós comunicación, Barcelona, 1993, pp. 242-245. J.-P. Oudart, «La suture», Cahiers du cinéma, n. ${ }^{\circ}$ 211-212, abril-mayo 1969, consultable en línea <www.fichierpdf.fr/2012/11/23/oudart/oudart.pdf>. Sobre la idea de enuciación cinematográfica véase también: C. Metz, L'Énonciation impersonnelle ou le site du film, Paris, Klincksieck, 1991.

50. Utilizo esta denominación como guiño al título de la película-manifiesto de E. Vertov pero en un sentido más general, esto es, el del punto de vista de un observador implicado con la instancia narrativa y enunciadora. Aumont nos habla en este sentido de la utilización del encuadre en el filme como manifestación de un punto de vista que no puede atribuirse a ningún personaje más que al del «hombre de la cámara» (in J. Aumont, «Vertov et la vue», Cinémas et réalités, CIEREC, Université de Saint-Étienne, 1984, pp. 23-44; citado en J. Aumont y M. Marie, op. cit., p. 176).

51. La ausencia de figuras masculinas positivas es significativa. Nada se dice, en efecto, del padre del niño de Zulema. Manuel, el chico que conoce Caye y que puede ser una posibilidad de salida para ella, resulta ser tan banal como cualquiera de sus otros clientes, Zulema renuncia además al voluntario de la Cruz Roja que parece enamorado de ella...

52. Especial El País: <http://elpais.com/diario/2008/07/06/eps/1215325611_850215.html>.

53. El lector reconocerá la referencia al filósofo Paul Ricœur pero también podemos recordar la visión del otro que nos transmitía Machado en los versos que abren nuestro artículo. 


\section{RESÚMENES}

Una de las transformaciones más flagrantes de la sociedad española de principios del nuevo siglo ha sido el cambio de país de emigración a país receptor. Tras una primera fase de asombro frente el fenómeno han ido surgiendo otras reacciones tendentes a estigmatizar la inmigración como «problema», dando como resultado una suerte de repliegue territorial nacionalista frente al otro. El cine español que, desde los años 90, había realizado un giro hacia discursos de tipo social, se ha hecho cargo de dicha transformación para observar y plantear cuestionamientos en torno a la construcción de una nueva sociedad. La película Princesas (León de Aranoa, 2005) propone en la construcción de su espacio fílmico una mirada a la inmigración que nos invita a un encuentro hospitalario con el otro. Analizar los recursos mediante los cuales el filme invita a romper las fronteras hostiles en la relación con la otredad es el objeto de nuestro artículo.

One of the most evidentt transformations in the early 21st century Spanish society is its evolution from being an "emigration country" to becoming a "host country". After a first reaction of astonishment towards this phenomenon, other kinds of reactions have progressively taken place in the society bringing as a result a sort of territorial and nationalist withdrawal: that is to say, the stigmatization of immigration as a "problem".

The recent Spanish cinema, that has developped since the 90's a social discourse, has explored this transformation to observe it and inquire the construction of a new society. The film Princesas (León de Aranoa, 2005) proposes in the construction of its filmic space a look on immigration inviting us to a hospitable meeting with the other. The aim of this article is to analyze the resources with which the film invites us to break the hostile borders in the relationship with otherness.

\section{ÍNDICE}

Palabras claves: Princesas, León de Aranoa, cine social español, cine e inmigración, transformación social España

Keywords: Princesas, León de Aranoa, Social Spanish cinema, cinema and immigration, Spanish social transformation

\section{AUTOR}

OLGA LOBO

Université Grenoble Alpes, ILCEA 